\title{
ELABORAT UČINKOVITOSTI PRIMARNE ŠUMSKE PROMETNE INFRASTRUKTURE - ALTERNATIVA STUDIJI PRIMARNOG OTVARANJA ŠUMA ILI SAMO PRIJELAZNO RJEŠENJE?
}

\author{
THE EFFECTIVENESS STUDY OF PRIMARY FOREST ROAD \\ TRAFFIC INFRASTRUCTURE - AN ALTERNATIVE TO STUDY \\ OF PRIMARY FOREST OPENING OR JUST A SHORT-TERM \\ SOLUTION?
}

Tibor PENTEK, Andreja ĐUKA*, Ivica PAPA, Darija DAMIĆ, Tomislav PORŠINSKY

\begin{abstract}
Sažetak
Planiranje šumskih prometnica, kao prva, nezaobilazna i vrlo važna faza uspostavljanja optimalne/najbolje moguće mreže primarne šumske prometne infrastrukture na terenu, može biti na: 1) strateškoj, 2) taktičkoj te 3) operativnoj razini. Strateško i taktičko planiranje odnose se na planiranje cjelokupne mreže primarnih šumskih prometnica, dok se operativno planiranje odnosi na planiranje pojedinačne šumske ceste. Rezultat taktičkog planiranja primarnih šumskih prometnica je, ili bi bar trebala biti, Studija primarnog otvaranja šuma pojedine gospodarske jedinice (dalje: Studija).

Nepostojanje (pod)zakonske obveze izrade Studije, dokumenta u kojemu bi se objedinili svi rezultati rada pri taktičkom planiranju primarne šumske prometne infrastrukture na razini gospodarske jedinice, predstavlja velik problem pri optimizaciji primarne šumske prometne infrastrukture, poglavito neotvorenih ili nedovoljno otvorenih šuma. Unatoč čestom ukazivanju na navedeni problem, ali i na mogućnosti njegova rješavanja/umanjenja, kroz značajan broj radova različitih autora koji su se u svojem znanstvenom radu bavili problematikom otvaranja šuma, rezultati istraživanja i konkretne preporuke do danas nisu naišle na širu primjenu u operativnome šumarstvu. Tijekom izrade Programa Ruralnog razvoja Republike Hrvatske za razdoblje 2014.-2020. (dalje: Program), EU je zatražila od Republike Hrvatske da osmisli dokument kojim će se analizirati i ocijeniti kvantiteta i kvaliteta prostornog rasporeda primarne šumske prometne infrastrukture određene gospodarske jedinice, utvrditi potreba daljnjega primarnog otvaranja šuma, definirati položaj idejnih trasa planiranih šumskih prometnica te uskladiti gustoća mreže primarnih šumskih prometnica na taktičkoj razini s preporučenim vrijednostima pojedinog reljefnog područja na strateškoj razini planiranja primarne šumske prometne infrastrukture.
\end{abstract}

Prof. dr. sc. Tibor Pentek, e-pošta: pentek@sumfak.hr; *Dr. sc. Andreja Đuka, e-pošta: aduka@sumfak.hr; Dr. sc. Ivica Papa, e-pošta: papa@sumfak.hr; Prof. dr. sc. Tomislav Poršinsky, e-pošta: porsinsky@sumfak.hr, Zavod za šumarske tehnike i tehnologije, Šumarski fakultet Sveučilišta u Zagrebu, Svetošimunska 25, HR - 10000 Zagreb 
U okviru Pravilnika o provedbi mjere M04 »Ulaganja u fizičku imovinu«, podmjere 4.3. »Potpora za ulaganja u infrastrukturu vezano uz razvoj, modernizaciju i prilagodbu poljoprivrede i šumarstva«, tipa operacije 4.3.3. »Ulaganje u šumsku infrastrukturu« iz Programa ruralnog razvoja Republike Hrvatske za razdoblje 2014.-2020. (NN 106/15) (dalje: Pravilnik) se nalazi prilog 1 - Obrazac za izradu Elaborata učinkovitosti mreže šumskih prometnica - primarne šumske prometne infrastrukture (dalje: Elaborat), koji je u potpunosti zadovoljio postavljene kriterije EU.

U radu se: 1) kritički raščlanjuju osnovne sastavnice Elaborata s posebnim naglaskom na njegovu sastavnicu B. Analiza postojeće mreže primarne šumske prometne infrastrukture, 2) detaljno pojašnjava metodologija izrade registra primarne šumske prometne infrastrukture, 3) opisuju novodefinirani kriteriji određivanja gustoće primarne šumske prometne infrastrukture, 4) u odnos se radi međusobne usporedbe dovode Elaborat i Studija, te 5) donose se preporuke o budućim aktivnostima usmjerenima ka poboljšanju taktičkog planiranja primarne šumske prometne infrastrukture.

KLJUČNE RIJEČI: taktičko planiranje primarnih šumskih prometnica, Elaborat učinkovitosti primarne šumske prometne infrastrukture, registar primarne šumske prometne infrastrukture, kriteriji određivanja gustoće primarne šumske prometne infrastrukture, Studija primarnog otvaranja šuma

\section{1. ŠTO JE ELABORAT UČINKOVITOSTI PRIMARNE ŠUMSKE PROMETNE INFRASTRUKTURE, KAKO JE, KADA I ZAŠTO/ ZBOG ČEGA OSMIŠLJEN?}

\section{WHAT IS THE EFFECTIVENESS STUDY OF PRIMARY FOREST ROAD TRAFFIC INFRASTRUCTURE, HOW, WHEN AND WHY IT WAS DEVELOPED?}

Tijekom izrade Programa, EU je zatražila od Republike Hrvatske dokument u kojemu se mogu pronaći podaci o postojećoj i planiranoj primarnoj šumskoj prometnoj infrastrukturi pojedine gospodarske jedinice. Traženi podaci u postojećim šumskogospodarskim planovima (Gospodarskim osnovama i Programima gospodarenja) su, prema ocjeni šumarskih stručnjaka EU, bili jako šturi i nedostatni za bilo kakvo ozbiljnije planiranje primarne šumske prometne infrastrukture, odnosno neodgovarajući kao polazište za projektiranje primarnih šumskih prometnica (izradu glavnih projekata šumskih cesta) na temelju kojih bi se ostvarivalo pravo šumovlasnika/šumoposjednika na sufinanciranje ulaganja sredstvima EU.

Time su vodeći šumarski stručnjaci u EU potvrdili dugogodišnje, skoro pa istovjetno stajalište znanstvenika (Contreras i Chung 2007, Çalişkan 2013, Danilović i Stojnić 2014, Demir 2007, Enache i dr. 2013, Hribernik i Potočnik 2013, Kiss i dr. 2015, Krč i Beguš 2013, Lugo i Gucinski 2000, Pentek 2002, Pentek i dr. 2007, Pentek i Poršinsky 2012, Pentek i dr. 2014, Potočnik i dr. 2005), ali i nekih kolega koji su vezani uz operativno šumarstvo iz Republike Hrvatske (Brajković 1997, Bumber 2011, Dundović 1996, Hodić i Jurušić 2011), koji se u svome znanstveno-istraživačkom, odnosno praktičnom radu bave problematikom u svezi s planiranjem/optimizacijom primarnih šumskih prometnica.

Od strane EU je naloženo Republici Hrvatskoj da osmisli dokument kojim će se: 1) analizirati i ocijeniti kvantiteta i kvaliteta prostornog rasporeda primarne šumske prometne infrastrukture određene gospodarske jedinice, 2) utvrditi potreba njezina daljnjeg primarnog otvaranja, 3) definirati položaj idejnih trasa planiranih šumskih cesta i 4) uskladiti gustoća mreže primarnih šumskih prometnica na taktičkoj razini s preporučenim vrijednostima pojedinog reljefnog područja na strateškoj razini planiranja primarne šumske prometne infrastrukture. Samo u slučaju potvrde potrebe daljnjeg primarnog otvaranja šuma te po definiranju položaja idejnih trasa planiranih šumskih prometnica, što će se dokazati predmetnim dokumentom, pristupa se fazi projektiranja šumskih cesta.

Vlada Republike Hrvatske je putem svojega Ministarstva poljoprivrede formirala Povjerenstvo za izradu Pravilnika o provedbi mjere M04 »Ulaganja u fizičku imovinu «, podmjere 4.3. »Potpora za ulaganja u infrastrukturu vezano uz razvoj, modernizaciju i prilagodbu poljoprivrede i šumarstva«, tipa operacije 4.3.3. »Ulaganje u šumsku infrastrukturu « iz Programa ruralnog razvoja Republike Hrvatske za razdoblje 2014. - 2020. (dalje: Pravilnik). Pravilnik je objavljen u NN 106/15, a njegov prilog 1 je Obrazac za izradu Elaborata.

Elaborat učinkovitosti primarne šumske prometne infrastrukture sadrži pet osnovnih sastavnica:

$\Rightarrow$ A. Opći podaci,

$\Rightarrow$ B. Analiza postojeće mreže primarne šumske prometne infrastrukture,

$\Rightarrow$ C. Planiranje/projektiranje idejne trase šumske ceste na karti i na terenu, 
$\Rightarrow$ D. Analiza unaprijeđene mreže primarne šumske prometne infrastrukture,

$\Rightarrow$ E. Rekapitulacija i ocjena opravdanosti primarnog otvaranja šuma

\section{SASTAVNICE ELABORATA UČINKOVITOSTI PRIMARNE ŠUMSKE PROMETNE INFRASTRUKTURE COMPONENTS OF THE EFFECTIVENESS STUDY OF PRIMARY FOREST ROAD TRAFFIC INFRASTRUCTURE}

U ovom su poglavlju opisane i pojašnjene sve sastavnice Elaborata, pri čemu je poseban naglasak stavljen na detaljniji prikaz sastavnice B. - Analiza postojeće mreže primarne šumske prometne infrastrukture, koja treba dati odgovor na pitanje o potrebi/svrsishodnosti daljnjeg primarnog otvaranja pojedine gospodarske jedinice (unaprjeđenja postojeće primarne šumske prometne infrastrukture) te je po tome ključna sastavnica Elaborata.

Za ogledni primjer, nekih priloga sastavnice B. Elaborata, odabrana je GJ »Javornik - Tisov vrh «, ukupne površine 4076,46 ha, kojom gospodari šumarija Korenica. U vertikalnom se pogledu pruža od 350 do 1648 m nadmorske visine, bogata je krškim fenomenima, te pripada planinskom (gorskom) reljefnom području. Obrasla površina GJ iznosi 3985,57 ha, u kojoj prevladavaju sjemenjače $(2992,94$ ha, $75,1 \%)$, dok ostatak obrasle površine otpada na panjače $(20,2 \%)$ i šikare (4,7 \%). Približno isti udjel obrasle površine, zauzimaju preborne (1902,58 ha, 47,7 \%) i raznodobne sastojine (1896,32 ha, 47,6 \%). Najzastupljenija je šumska zajednica brdska bukova šuma s mrtvom koprivom $(1760,04$ ha, 44,2 \%). Drvna zaliha GJ iznosi $1.106 .479 \mathrm{~m}^{3}$, najzastupljenija vrsta je obična bukva ( $68,5 \%$ drvne zalihe GJ), prosječni godišnji prirast iznosi $23.480 \mathrm{~m}^{3}$, a propisani 10-godišnji etat etat $181.055 \mathrm{~m}^{3}$.

\subsection{Opći podaci (Sastavnica A. Elaborata) - General information (Effectiveness Study Component A.)}

Opći podaci, kao što im i samo ime govori, daju opće informacije o podnositelju zahtjeva za financiranje ulaganja te o području zahvata primarnog otvaranja šuma. Ova sastavnica Elaborata služi za procjenu ispunjavanja općih uvjeta podnositelja zahtjeva kandidiranog za financijsku potporu ulaganju u primarnu šumsku prometnu infrastrukturu.

Opći podaci koji se mogu pronaći u Elaboratu su:

$\Rightarrow 1$. Osnovni podaci o podnositelju zahtjeva,

$\Rightarrow 2$. Osnovni podaci o području zahvata primarnog otvaranja šuma,

$\Rightarrow 3$. Rješenje iz šumskogospodarskog plana,
$\Rightarrow 4$. Dokaz o vlasništvu i posjedništvu u području zahvata primarnog otvaranja šuma,

$\Rightarrow 5$. Pregledna karta gospodarske jedinice* koja je predmet zahvata primarnog otvaranja šuma.

2.2 Analiza postojeće mreže primarne šumske prometne infrastrukture (Sastavnica B. Elaborata) Analysis of existing primary forest traffic infrastructure network (Effectiveness Study Component B.)

Analiza postojeće mreže primarne šumske prometne infrastrukture, kroz svojih 11 definiranih podsastavnica, treba jasno i nedvosmisleno ocijeniti kvantitetu i kvalitetu prostornog rasporeda postojeće primarne šumske prometne infrastrukture određene gospodarske jedinice. U nastavku se detaljno opisuju navedene podsastavnice (zasebno ili objedinjeno kada čine neraskidivu logičnu cjelinu), a pojašnjavaju se i metode/postupci koje je bilo potrebno razviti (ili unaprijediti), a koje su bile preduvjet kvalitetnog dostizanja cilja u okviru pojedine podsastavnice.

Obavezni su prilozi sastavnice B. Elaborata:

1. Slojnička karta gospodarske jedinice s ucrtanom granicom gospodarske jedinice, unutarnjom podjelom i registrom postojeće primarne šumske prometne infrastrukture (M 1:25000 ili krupnije, a slojnice sa TK 25),

2. Registar postojeće primarne šumske prometne infrastrukture gospodarske jedinice (tablični prikaz),

3. Karta drvne zalihe po odjelima/odsjecima gospodarske jedinice (M 1:25000 ili krupnije),

4. Karta ukupnog desetogodišnjeg brutto etata po odjelima/ odsjecima gospodarske jedinice (M 1:25000 ili krupnije),

5. Karta kategorija opasnosti pojave šumskoga požara po odjelima/odsjecima gospodarske jedinice (M 1:25000 ili krupnije),

6. Određivanje pripadajuće kategorije reljefnog područja za gospodarsku jedinicu (tabelarni prikaz),

7. Karta postojeće geometrijske (euklidske) udaljenosti privlačenja drva gospodarske jedinice (M 1:25000 ili krupnije),

8. Prikaz postojeće geometrijske (euklidske) udaljenosti privlačenja drva, drvne zalihe i ukupnog desetogodišnjeg bruto etata po odjelima/odsjecima gospodarske jedinice (tabelarni prikaz),

9. Raščlamba primarne relativne otvorenosti za postojeću primarnu šumsku prometnu infrastrukturu u gospodarskoj jedinici (M 1:25000 ili krupnije),

* Termin gospodarska jedinica u kontekstu Elaborata, koji se koristi u nastavku ovoga rada, se odnosi na gospodarsku jedinicu ili veći šumski kompleks (grupu odjela/odsjeka) koji je predmet zahvata primarnog otvaranja šuma. 
10. Raščlamba primarne relativne otvorenosti za postojeću primarnu šumsku prometnu infrastrukturu u gospodarskoj jedinici (tabelarni prikaz),

11. Rekapitulacija parametara procjene kvantitete i kvalitete postojeće mreže primarnih šumskih prometnica u gospodarskoj jedinici (tabelarni prikaz).

\subsubsection{Registar postojeće primarne šumske prometne infrastrukture - Existing primary forest traffic infrastructure registry}

Za svako je kvalitetno planiranje, pa tako i planiranje primarnih šumskih prometnica na taktičkoj razini, nužno poznavati postojeće stanje, odnosno u ovom slučaju imati detaljan uvid u postojeću primarnu šumsku prometnu infrastrukturu (Pentek i dr. 2005). Stoga je izrada registra primarnih šumskih prometnica prvi, nezaobilazan i vrlo važan korak pri analizi postojeće mreže primarne šumske prometne infrastrukture. Registar postojeće primarne šumske prometne infrastrukture sastoji se od slikovnog (prilog B.1. Elaborata) i tabelarnog prikaza (prilog B.2. Elaborata koji sadrži tri tablice B.2.1., B.2.2. i B.2.3.)

Na razini Republike Hrvatske prije izrade Elaborata nije postojala jedinstvena metodologija izrade registra primarne šumske prometne infrastrukture pojedine gospodarske jedinice za potrebe taktičkog planiranja mreže primarne šumske prometne infrastrukture. Postojala je spomenuta metodologija samo na razini državnih šuma Republike Hrvatske kojima upravlja trgovačko društvo »Hrvatske šume« d.o.o., a kako je njena prva inačica, koja je kasnije dorađivana i koja je nastala u suradnji »Hrvatskih šuma « d.o.o. i Zavoda za šumarske tehnike i tehnologije Šumarskog fakulteta Sveučilišta u Zagrebu (Pentek i dr. 2008, Papa i dr. 2015), bila dosta kvalitetna, ista je uzeta kao polazište, te je za potrebe Elaborata poboljšana.

\subsubsection{Metodologija izrade registra primarne šumske prometne infrastrukture - Methodology of primary forest traffic infrastructure registry development}

Registar primarne šumske prometne infrastrukture, tablični dio koji se izrađuje u tabličnom kalkulatoru (npr. Microsoft Excel) i grafički dio koji se izrađuje u GIS aplikaciji (npr. ArcGIS ili QGIS) uspostavlja se na razini gospodarske jedinice.

Svakoj se sastavnici primarne šumske prometne infrastrukture, i na grafičkom i u tabličnom prikazu, pridružuje jedinstveni registarski broj koji se sastoji od tri grupe oznaka složenih od velikih tiskanih slova i arapskih brojeva.

Prva grupa oznaka je troznamenkasti arapski broj, koji predstavlja identifikacijski broj gospodarske jedinice u šumskogospodarskoj podjeli područja Republike Hrvatske. Ukoliko gospodarska jedinica nema pripadajući identifikacijski broj, umjesto njega se upisuje skraćeni naziv (duljine tri tiskana slova) gospodarske jedinice.
Druga grupa oznaka se sastoji od velikog tiskanog slova koje opisuje kategoriju ceste (A - javna i nerazvrstana cesta, B - šumska gospodarska i šumska protupožarna cesta) i jednoznamenkastog arapskog broja koji definira cestu prema kriteriju njezina značenja u cjelovitoj mreži primarnih šumskih prometnica određene gospodarske jedinice (1 - glavna primarna šumska prometnica, 2 - sporedna primarna šumska prometnica, 3 - prilazna primarna šumska prometnica, a koje odgovaraju definicijama glavne, sporedne i prilazne šumske ceste prema Šikiću i dr. (1988)).

Treća grupa oznaka je troznamenkasti arapski broj koji određuje redoslijed šumske, javne ili nerazvrstane ceste $\mathrm{u}$ gospodarskoj jedinici.

Snimanje i unos podataka moguće je obaviti na dva načina: 1. skeniranjem i geokodiranjem dovoljno točnih kartografskih podloga (HOK mjerila M 1:5000 ili TK 25) te vektoriziranjem cesta u obliku linija, 2. prikupljanjem podataka pomoću globalnog pozicijskog sustava (GPS-a) odgovarajuće preciznosti uz uredsku prilagodbu i obradu podataka pogodnim računalnim programima.

Debljina linija se u grafičkom prikazu za sve registrirane sastavnice primarne šumske prometne infrastrukture prilagođava mjerilu grafičkog prikaza. Vrsta i boja linije pojedine grupe primarnih šumskih prometnica definirana je kako slijedi:

$\Rightarrow$ javne ceste s asfaltnim kolnikom - puna linija crvene boje,

$\Rightarrow$ javne ceste s kamenom kolničkom konstrukcijom (tucanik ili šljunak) - isprekidana linija crvene boje,

$\Rightarrow$ šumske ceste s asfaltnim kolnikom - puna linija ljubičaste boje,

$\Rightarrow$ šumske ceste s kamenom kolničkom konstrukcijom (tucanik ili šljunak) - puna linija plave boje,

$\Rightarrow$ šumske ceste bez kolničke konstrukcije - isprekidana linija plave boje,

$\Rightarrow$ planirane šumske ceste (idejne trase budućih šumskih cesta) - točkasta linija plave boje.

Registarske oznake sastavnica primarne šumske prometne infrastrukture su crne boje, upisuju se u pravokutnik također crne boje, koji se na grafičkom prikazu smješta pokraj primarne šumske prometnice na lako uočljivo mjesto. Veličina pravokutnika i veličina registarskih oznaka prilagođena je mjerilu grafičkog prikaza.

2.2.3 Kriteriji određivanja gustoće primarne šumske prometne infrastrukture - Criteria for determining density of primary forest traffic infrastructure

Na temelju uspostavljenog registra i uz primjenu kriterija određivanja gustoće, moguće je izračunati gustoću (klasičnu otvorenost) primarne šumske prometne infrastrukture. 


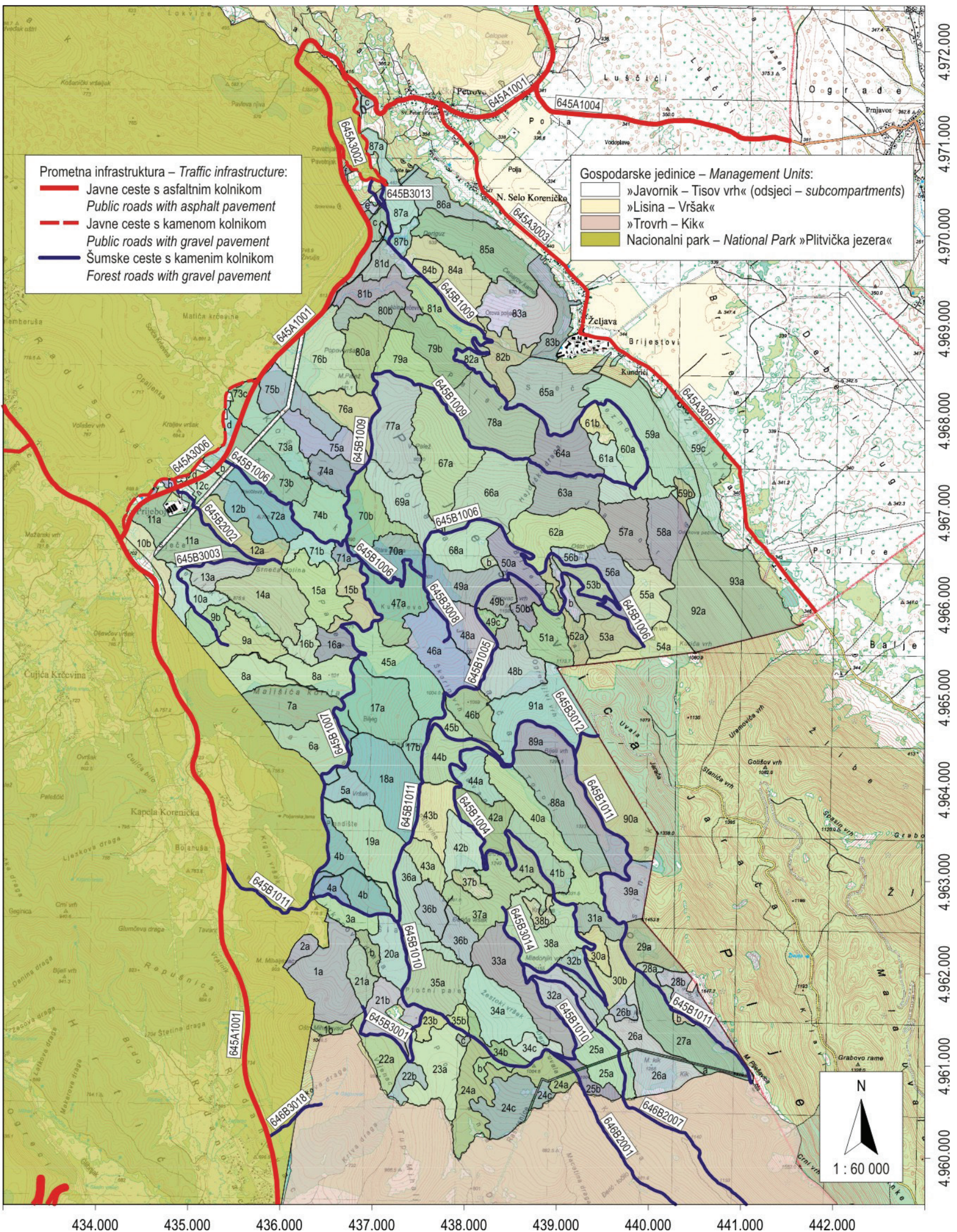

Slika 1. Slojnička karta gospodarske jedinice "Javornik - Tisov vrh» (prilog B.1 Elaborata)

Fig. 1 Contour line map of management unit »Javornik - Tisov Vrh» (Effectiveness Study Appendix B.1) 


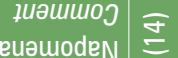

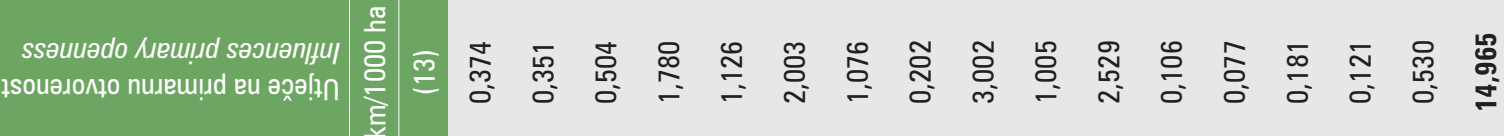

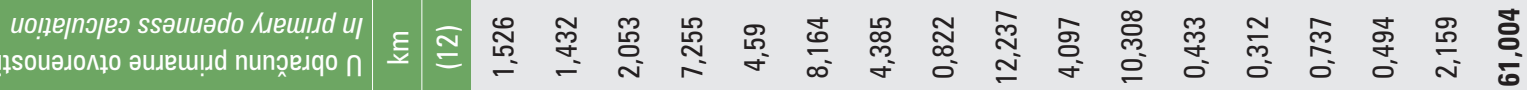

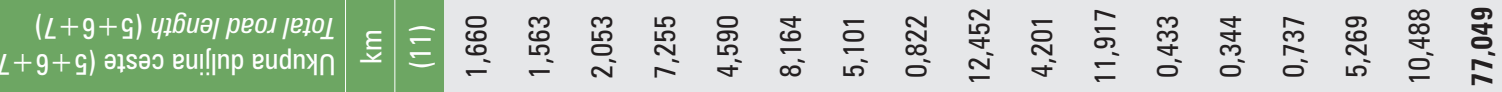

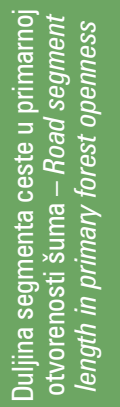

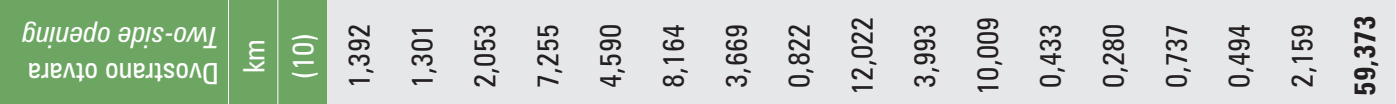

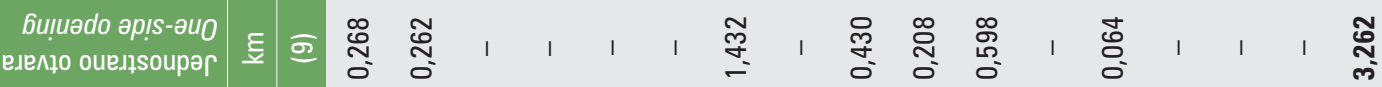

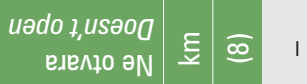

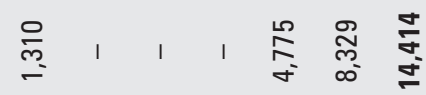

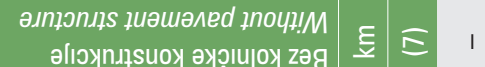

은 믐
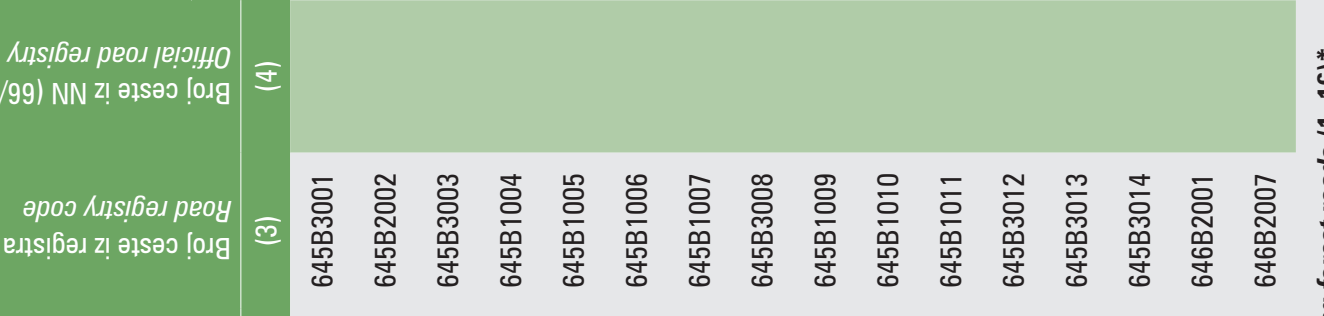


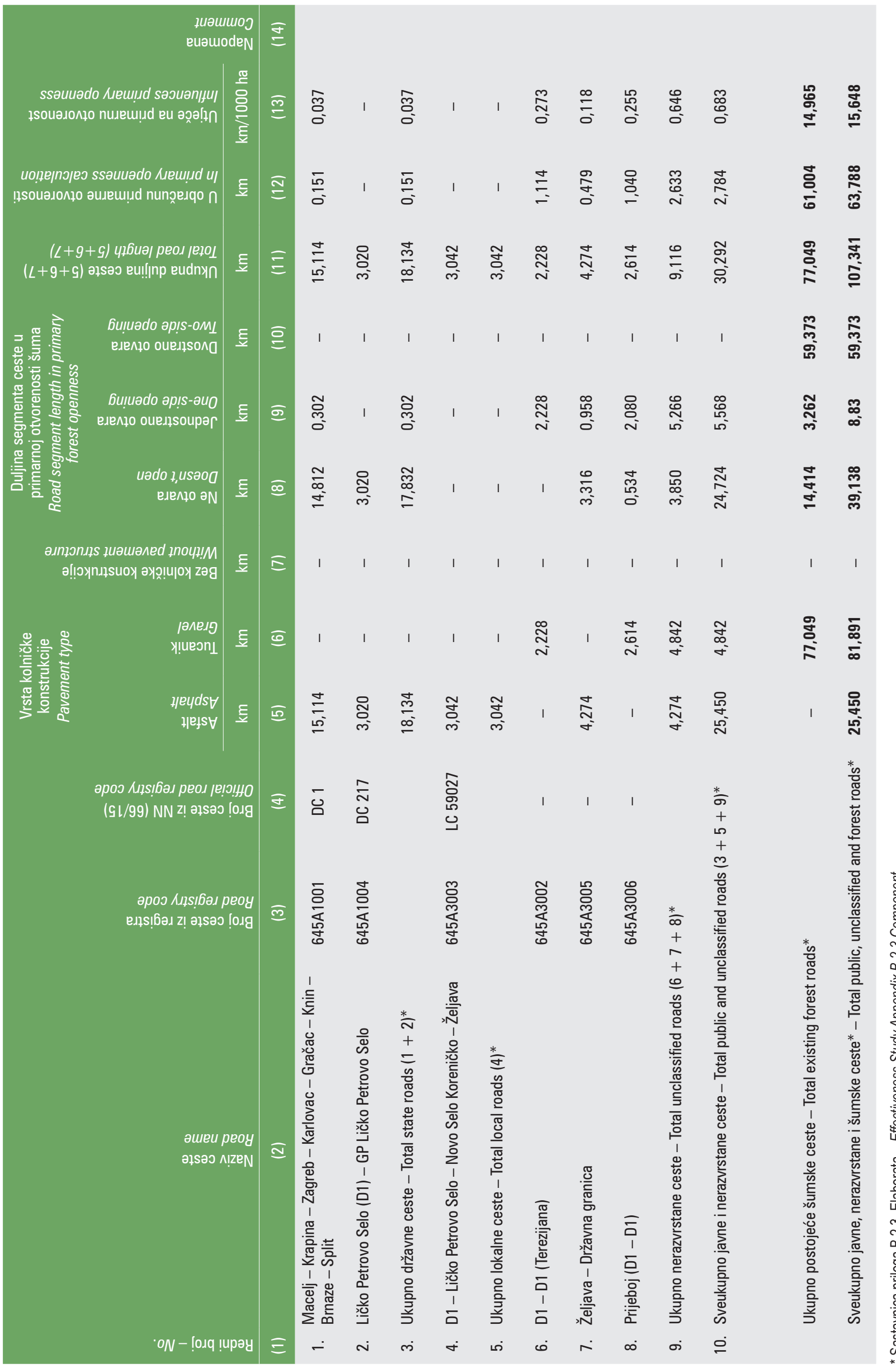


Gustoća primarne šumske prometne infrastrukture ${ }^{* *}$ (šumske, javne i nerazvrstane ceste) iskazuje se $\mathrm{u} \mathrm{km} / 1000 \mathrm{ha}$, a određuje se za područje gospodarske jedinice. Pri izračunu gustoće primarne šumske prometne infrastrukture, uslijed održivoga gospodarenja šumom na površini čitave gospodarske jedinice, u obzir se uzima njena ukupna površina šume i šumskog zemljišta.

Duljina pojedine sastavnice primarne šumske prometne infrastrukture koja se uzima u obzir pri obračunu gustoće primarne šumske prometne infrastrukture određuje se na temelju osnovnog/eliminacijskog i posebnih/prostornih kriterija.

\section{Osnovni/eliminacijski kriterij}

Šumska, javna ili nerazvrstana cesta, odnosno njezina pojedina dionica koja se uzima u obzir pri obračunu gustoće primarne šumske prometne infrastrukture, mora zadovoljavati ove osnovne/eliminacijske podkriterije:

a. ima izgrađenu kolničku konstrukciju (gornji ustroj),

b. u većoj mjeri ispunjava bitne minimalne tehničke značajke nužne za prijevoz drva solo kamionom,

c. ne postoji prometnom signalizacijom regulirano ograničenje osovinskog prometnog opterećenja manje od 10 tona i ukupnog prometnog opterećenja manje od 26 tona,

d. do ceste se može privlačiti drvo, pri čemu se šumska vozila neće kretati po nešumskom zemljištu (poljoprivredno zemljište, urbanizirano zemljište i sl.).

\section{Posebni/prostorni kriteriji}

Šumska, javna ili nerazvrstana cesta, odnosno njezina pojedina dionica, koja se može koristiti pri održivom gospodarenju šumama, a poglavito za utovar šumskih drvnih proizvoda, koja čitavom svojom duljinom prolazi kroz šumu i/ ili preko šumskog zemljišta i koja šumu otvara dvostrano, uzima se u obračun gustoće primarne šumske prometne infrastrukture čitavom svojom duljinom (100 \% duljine).

\footnotetext{
** Gustoća cesta je dobro poznat parametar, koji je dugo vremena u šumarskim krugovima predstavljao osnovnu veličinu prema kojoj se određivala razina dosegnute postojeće, ali i željene primarne otvorenosti nekoga šumskog područja (Pentek i dr. 2011). Kao pokazatelj otvorenosti šuma, gustoća cesta je brojčani podatak koji ne govori puno o kvaliteti prostornoga rasporeda primarnih prometnica šumskoga područja, već samo o njihovoj kvantiteti te se stoga samo na osnovi ovog parametra ne može dovoljno pouzdano opisati funkcionalnost i provesti ocjena postojećeg, odnosno procjena unaprijeđenog (poboljšanog, razvijenog) primarnog šumskog transportnog sustava (Pentek i dr. 2004). Razvojem GIS-a i uspostavom digitalnog registra primarne prometne šumske infrastrukture ovaj je osnovni nedostatak otklonjen (Pentek i dr. 2005).
}

Šumska, javna ili nerazvrstana cesta, odnosno njezina pojedina dionica, koja se može koristiti pri održivom gospodarenju šumama, a poglavito za utovar šumskih drvnih proizvoda, koja čitavom svojom duljinom prolazi kroz šumu i/ ili preko šumskog zemljišta i koja šumu, zbog različitih ograničenja, otvara jednostrano, uzima se u obračun gustoće primarne šumske prometne infrastrukture s polovicom svoje duljine (50 \% duljine).

Šumska, javna ili nerazvrstana cesta, odnosno njezina pojedina dionica, koja se može koristiti pri održivom gospodarenju šumama, a poglavito za utovar šumskih drvnih proizvoda, koja prolazi granicom gospodarske jedinice (dalje: granica), ili najviše do $250 \mathrm{~m}$ udaljenosti od granice s njene vanjske ili najviše do $125 \mathrm{~m}$ udaljenosti od granice s njene unutarnje strane, a čija trasa generalno prati smjer pružanja granice, uzima se u obračun gustoće primarne šumske prometne infrastrukture s polovicom svoje duljine (50\% duljine).

Šumska, javna ili nerazvrstana cesta, odnosno njezina pojedina dionica (minimalne duljine $500 \mathrm{~m}$ ), koja se može koristiti pri održivom gospodarenju šumama, a poglavito za utovar šumskih drvnih proizvoda, koja dolazi do granice gospodarske jedinice (dalje: granica) pod približno pravim kutom $\left(90^{\circ} \pm 20^{\circ}\right)$ i na granici završava, uzima se u obračun gustoće primarne šumske prometne infrastrukture s duljinom od $250 \mathrm{~m}$. Ukoliko je duljina spomenute sastavnice primarne šumske prometne infrastrukture manja od 500 $\mathrm{m}$, ista se uzima u obračun otvorenosti s polovicom svoje duljine (50 \% duljine). Ukoliko predmetna sastavnica primarne šumske prometne infrastrukture ne završava na granici već ulazi u područje zahvata primarnog otvaranja šuma, na nju se unutar spomenute granice primjenjuju ostali opći i posebni kriteriji određivanja gustoće primarne šumske prometne infrastrukture.

Šumska, javna ili nerazvrstana cesta, odnosno njezina pojedina dionica, koja se može koristiti pri održivom gospodarenju šumama, a poglavito za utovar šumskih drvnih proizvoda, koja dolazi blizu granice gospodarske jedinice (dalje: granica) koja je predmet zahvata primarnog otvaranja šuma pod približno pravim kutom $\left(90^{\circ} \pm 20^{\circ}\right)$, ali završava $\mathrm{s}$ vanjske strane granice, uzima se $\mathrm{u}$ obračun gustoće primarne šumske prometne infrastrukture s duljinom od $250 \mathrm{~m}$ umanjenom za polovicu udaljenosti njezina završetka od granice.

Nakon primjene gore navedenog osnovnog/eliminacijskog kriterija (s četiri podkriterija) i pet posebnih/prostornih kriterija ispunjavaju se tri tablice koje su sastavni, tablični dio registra primarne šumske prometne infrastrukture (prilog B.2 Elaborata).

U hrvatskome šumarstvu trenutno važeće kriterije za određivanja gustoće primarne šumske prometne infrastrukture definiraju »Tehnički uvjeti za gospodarske ceste«(Šikić i dr. 
1989), koji su u sažetom obliku uključeni u Pravilnike o uređivanju šuma (NN 111/06, NN 141/08) te (NN 79/15). $\mathrm{Na}$ navedene kriterije, više autora (Bumber 2011, Đuka 2014, Lepoglavec 2014, Pentek i dr. 2011) u svojim objavama daje kritičke osvrte s obzirom na neke nejasnosti/nedorečenosti, te daju prijedloge za njihovo bolje određivanje, a koji su većinom ugrađeni u Pravilnik o provedbi mjere M04... (NN 106/15).

Uspostavljeni Registar postojeće primarne šumske prometne infrastrukture gospodarske jedinice »Javornik - Tisov vrh«, kao primjer priloga B.1. Elaborata (u prilagođenom mjerilu za objavu u časopisu) i koji je izrađen prema metodologiji iz potpoglavlja 2.2.2, prikazuje slika 1 te tablica 1 (prilog B.2.1 Elaborata) i tablica 2 (prilog B.2.2 Elaborata). Prilog B.2.3 Elaborata, predstavlja rekapitulaciju prethodna dva priloga i u ovome radu nije zasebno iskazan, već su unutar tablica 1 i 2, označene njegove sastavnice. Posebno valja istaknuti, da su zaglavlja tablica priloga B.2 Elaborata, nadopunjena sa tri kolone $(8,9 \mathrm{i} 10)$ iz razloga što nedovoljno kvalitetno opisuju rezultate kriterija određivanja gustoće primarne šumske prometne infrastrukture iz potpoglavlja 2.2.3, odnosno krajnjemu korisniku nije jasan način obračuna duljine koja sudjeluje u primarnoj otvorenosti, bez iskazanih vrijednosti duljina segmenata pojedinih cesta u primarnoj otvorenosti šuma (ne otvara šumu, jednostrano ili dvostrano otvara šumsku površinu). Navedeno predstavlja nedostatak Pravilnika o provedbi mjere M04... (NN 106/15), koji se može izbjeći i pisanim obrazloženjem za svaku prometnicu unutar registra, kao na primjer:

$\Rightarrow$ Državna cesta D1 (645A1001), ukupne je duljine 421,2 km (Macelj - Krapina - Zagreb - Karlovac - Gračac Knin - Brnaze - Split), a prolazi uz zapadnu i sjevernu granicu gospodarske jedinice Javornik - Tisov vrh na duljini od $15,114 \mathrm{~km}$. Uzak zaštitni pojas te strmi i visoki pokosi zasjeka i usjeka predmetne javne prometnice, isključuju mogućnost formiranja pomoćnih stovarišta u njenom zaštitnome pojasu, kao i odobravanje Elaborata privremene regulacije prometa (Pravilnik o sadržaju, namjeni i razini razrade prometnoga elaborata za ceste NN 140/13), osim na proširenju uz rub odsjeka 75b i 76 b, ukupne duljine $302 \mathrm{~m}$. S obzirom, da se duljina ovog segmenta predmetne javne ceste odnosi na jednostrano otvaranje šumske površine (sukladno 2. prostornom kriteriju obračuna gustoće primarne šumske prometne infrastrukture), ona sudjeluje sa $0,151 \mathrm{~km}$ u obračunu primarne otvorenosti, odnosno sa $0,037 \mathrm{~km} / 1000$ ha utječe na primarnu otvorenost GJ Javornik - Tisov vrh, ili

$\Rightarrow$ Šumska cesta »Kapela Korenička - Mala Plješivica» (645B1011), ukupne je duljine 11,917 km. Predmetna šumska cesta, dvostrano otvara površinu GJ Javornik Tisov vrh na duljini od 10,009 km (sukladno 1. prostornom kriteriju obračuna gustoće primarne šumske pro- metne infrastrukture), odnosno jednostrano na duljini od $0,598 \mathrm{~km}$ (sukladno 3. prostornom kriteriju obračuna gustoće primarne šumske prometne infrastrukture), a preostala duljina od $1310 \mathrm{~m}$ ne sudjeluje u otvaranju šumske površine, već povezivanju s državnom cestom D1 (645A1001). Navedenim šumska cesta sudjeluje sa $10,308 \mathrm{~km}$ u obračunu primarne otvorenosti, odnosno sa $2,529 \mathrm{~km} / 1000$ ha utječe na primarnu otvorenost GJ Javornik - Tisov vrh.

Registar postojećih šumskih cesta GJ Javornik - Tisov vrh (tablica 1), obuhvaća šesnaest šumskih cesta, ukupne duljine $77,049 \mathrm{~km}$, od koje na jednostrano otvaranje predmetne šumske površine otpada $3,262 \mathrm{~km}$, odnosno 59,373 $\mathrm{km}$ na dvostrano otvaranje šumske površine, a 14,414 km primarno ne otvara navedenu gospodarsku jedinicu. Uslijed posebnih/prostornih kriterija obračuna gustoće primarne šumske prometne infrastrukture, postojeće šumske ceste sudjeluju sa duljinom od $61,004 \mathrm{~km}$, koje primarno otvaraju GJ Javornik - Tisov vrh sa 14,965 km / 1000 ha.

U registru javnih i nerazvrstanih cesta GJ Javornik - Tisov vrh (tablica 2), ukupna duljina svih šest cesta iznosi 30,292 $\mathrm{km}$, od koje na jednostrano otvaranje predmetne šumske površine otpada $5,568 \mathrm{~km}$, odnosno $24,724 \mathrm{~km}$ primarno ne otvara navedenu gospodarsku jedinicu. Uslijed osnovnih/eliminacijskih te posebnih/prostornih kriterija obračuna gustoće primarne šumske prometne infrastrukture, postojeće javne i nerazvrstane ceste sudjeluju u obračunu sa duljinom od 2,784 km, čime primarno otvaraju GJ Javornik - Tisov vrh sa 0,683 km / 1000 ha.

Gustoća postojeće primarne šumske prometne infrastrukture (svih šumskih te onih javnih i nerazvrstanih cesta koje se mogu koristiti pri održivome gospodarenju šumama) iznosi 15,648 km / 1000 ha. U odnosu na najveću dozvoljenu gustoću primarne šumske prometne infrastrukture planinskog (gorskog) reljefnog područja $(22,5 \mathrm{~km} / 1000$ ha) koja se sufinancira ulaganjem sredstvima EU, postojeća je u GJ Javornik - Tisov vrh niža za 6,852 km / 1000 ha. S obzirom da površina predmetne GJ iznosi 4076,46 ha, najveća duljina idejnih trasa budućih šumskih cesta koje se mogu izgraditi do postizanja najveće dozvoljene gustoće primarne šumske prometne infrastrukture (uz pretpostavku da sve idejne trase budućih šumskih cesta u izračun gustoće primarne šumske prometne infrastrukture ulaze s duljinom od $100 \%$, tj. dvostrano otvaraju šumsku površinu), iznosi $27,93 \mathrm{~km}$

\subsubsection{Tematske karte gospodarske jedinice - Thematic maps of management unit}

U postupku analize postojeće mreže primarne šumske prometne infrastrukture izrađuju se, u mjerilu M 1:25000 ili krupnijem, tri tematske karte: 1) karta drvne zalihe, 2) karta ukupnog desetogodišnjeg bruto etata i 3) kategorija opa- 
snosti pojave šumskog požara, gdje se svi tematski sadržaji povezuju s odjelima/odsjecima predmetne gospodarske jedinice. Navedene tematske karte dobro opisuju zahtijeve za dodatnim otvaranjem šumske površine i obavezne su sastavnice Elaborata, a ostale tematske karte se, prema potrebi i sukladno procjeni ovlaštenog inženjera šumarstva za šumske prometnice i šumarsko graditeljstvo pri Hrvatskoj komori inženjera šumarstva i drvne tehnologije, mogu priložiti Elaboratu, kao npr: karta nagiba i neravnosti terena (Đuka i dr. 2015), karta kamenitosti i stjenovitosti terena (Đuka i Poršinsky 2015), karta smjera privlačenja drva (Đuka 2014, Krč i Košir 2008) i dr.

\subsubsection{Određivanje pripadajuće kategorije reljefnog područja - Defining relief area categories}

Svaka kategorija reljefnog područja: nizinsko, prigorsko/ brdsko, gorsko/planinsko i krško, sa stajališta primarnog otvaranja šuma, je karakterizirana specifičnim oblikom mreže primarne šumske prometne infrastrukture. Također je za svaku kategoriju reljefnog područja definirana ciljana gustoća primarne šumske prometne infrastrukture kao i ciljana geometrijska udaljenost privlačenja drva. U Programu i u Pravilniku se jasno definirane najveće dopuštene vrijednosti gustoće primarne šumske prometne infrastrukture, stoga je i za gospodarsku jedinicu koja je predmet primarnog otvaranja šuma važno točno odrediti u kojoj se kategoriji reljefnog područja nalazi. Na temelju 10 parametara određuje se kategorija reljefnog područja pojedine gospodarske jedinice, a radi jednostavnijeg određivanja svaka je kategorija reljefnog područja opisana kako slijedi:

$\Rightarrow$ Nizinsko reljefno područje - je ravno reljefno područje bez uzvisina, nadmorske visine najčešće od 0 do $200 \mathrm{~m}$. Sa gledišta otvaranja šuma primarnim šumskim prometnicama visinska razlika u nizinskom reljefu na duljini od $1 \mathrm{~km}$ karakteristične šumske ceste iznosi u pravilu do $20 \mathrm{~m}$, nagib padina je do 1:10, nabranost terena je neznatna, a izbor tehničkih elemenata trase šumske ceste je slobodan. Mreža šumskih cesta nizinskog područja ima uglavnom pravilan oblik, usporedne šumske ceste se nalaze na približno jednakoj udaljenosti, prolaze postojećim prosjekama i zatvaraju površine pravilnog oblika. Ciljana gustoća primarne šumske prometne infrastrukture iznosi $15 \mathrm{~km} / 1000 \mathrm{ha}$, a ciljana geometrijska udaljenost privlačenja drva $330 \mathrm{~m}$.

$\Rightarrow$ Brdsko (prigorsko) reljefno područje - odlikuje se uzvisinama visine do $500 \mathrm{~m}$. Sa gledišta otvaranja šuma primarnim šumskim prometnicama visinska razlika u brdskom (prigorskom) reljefu na duljini od $1 \mathrm{~km}$ karakteristične šumske ceste iznosi u pravilu od 20 do $80 \mathrm{~m}$, nagib padina je od 1:10 do 1:3, nabranost terena je izražena, a izbor tehničkih elemenata trase šumske ceste je djelomično jače ograničen. Mreža šumskih cesta sastoji se od tzv. etažnih, gotovo paralelnih i po slojnicama po- loženih šumskih cesta te između njih dijagonalnih, spojnih šumskih cesta. Opisana mreža šumskih cesta ima oblik očica nepravilne mreže i karakteristična je za brdska (prigorska) područja nerazvijene hidrografije. U brdskim (prigorskim) područjima razvijene hidrografije trase šumskih cesta prate vodotoke, mreža šumskih cesta ima oblik žila ili perastog lišća, a na kraju doline poprima oblik lepeze. Ciljana gustoća primarne šumske prometne infrastrukture iznosi $20 \mathrm{~km} / 1000 \mathrm{ha}$, a ciljana geometrijska udaljenost privlačenja drva $250 \mathrm{~m}$.

$\Rightarrow$ Planinsko (gorsko) reljefno područje - to je reljefno područje s uzdignutim dijelovima zemljine kore višima od $500 \mathrm{~m}$. Sa gledišta otvaranja šuma primarnim šumskim prometnicama visinska razlika u planinskom (gorskom) reljefu na duljini od $1 \mathrm{~km}$ karakteristične šumske ceste iznosi u pravilu više od $80 \mathrm{~m}$, nagib padina je od 1:3 do 1:0, nabranost terena je vrlo jaka, a izbor tehničkih elemenata trase šumske ceste je minimalan. Mreža šumskih cesta, ovisno o stupnju razvijenosti hidrografske mreže poprima oblike slične opisanima za brdsko (prigorsko) reljefno područje. Ukoliko se radi o krškom reljefu unutar planinskog (gorskog) reljefnog područja, tzv. visokom kršu, mreža primarnih šumskih prometnica prilagođava se krškim fenomenima te poprima oblik zatvorene mreže izrazito nepravilnih očica. Ciljana gustoća primarne šumske prometne infrastrukture iznosi $25 \mathrm{~km} / 1000$ ha, a ciljana geometrijska udaljenost privlačenja drva $200 \mathrm{~m}$.

$\Rightarrow$ Krško reljefno područje - je tip reljefa koji se razvija na tlu sastavljenom od topljivih stijena (kalcijevog ili magnezijevog karbonata). Osnovna je karakteristika krškog reljefa izražena selektivna topljivost stijena, posljedica čega je izrazito razvijen reljef sa mnogo udubina i uzvisina. Obično se razvija u planinskom (gorskom) reljefu. Sa stajališta otvaranja šumskim cestama ovdje rastu degradirane šumske sastojine i šumske kulture (tzv. niski krš) primarno općekorisnih funkcija šuma u mediteranskom i submediteranskom pojasu. Ciljana gustoća primarne šumske prometne infrastrukture iznosi 15 $\mathrm{km} / 1000$ ha, a ciljana geometrijska udaljenost privlačenja drva $330 \mathrm{~m}$.

Uz pojavnosti terenskih i klimatskih čimbenika te šumske vegetacije, uz pojedina je reljefna područja šuma povezana i: 1) mogućnost primjene pojedinih sustava pridobivanja drva (Đuka 2014, Kühmaier i Stampfer 2010, Pentek i dr. 2008), odnosno šumskih strojeva (Beuk i dr. 2007, Đuka i dr. 2016, Mihelič i Krč 2009, Poršinsky i dr. 2016, Tomašić 2012, Trajanov i dr. 2013A, Visser i Stampfer 2015, Visser i Berkett 2015) te 2) njima pogodnih oblika mreže primarne i sekundarne šumske infrastrukture (Pentek i dr. 2011). U navedenome kontekstu, osim troškovne konkurentnosti (Cavalli i Grigolato 2009, Chung i dr. 2008, Contreras i 


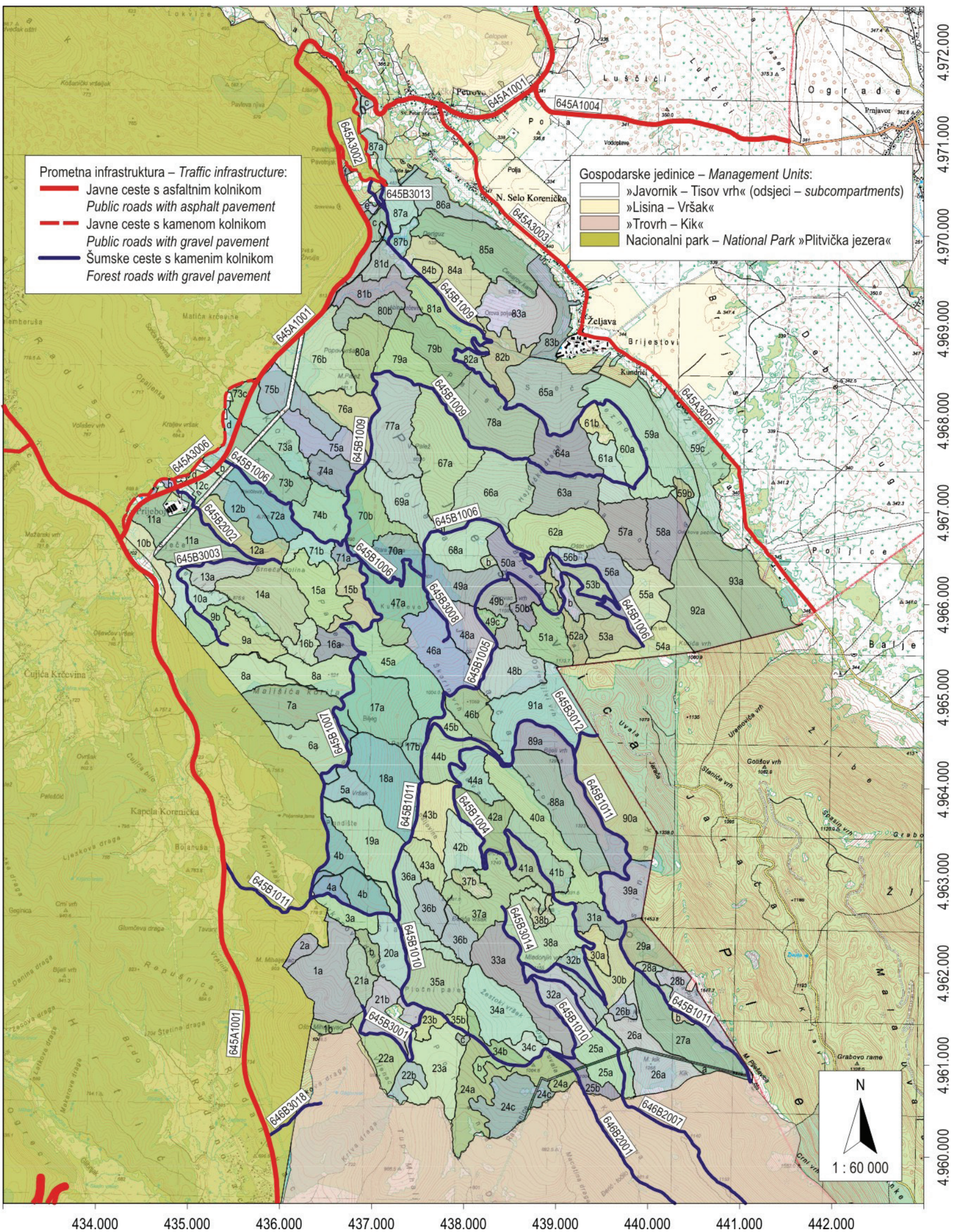

Slika 2. Karta postojeće geometrijske (euklidske) udaljenosti privlačenja drva gospodarske jedinice "Javornik - Tisov vrh» (prilog B.7 Elaborata) Fig. 2 Map of geometric (euclidean) timber extraction distance in management unit »Javornik - Tisov Vrh« (Effectiveness Study Appendix B.7) 
Chung 2011, Danilović i dr. 2013, Hayati i dr. 2012, Pičman i dr. 1997, Trajanov i dr. 2013B) ne smije se zanemariti i pogodnost metoda izradbe drva (Danilović i dr. 2014, Huber i Stampfer 2015, Marčeta i dr. 2014) te okolišna pogodnost izvođenja šumskih radova, koja se ogleda kroz: 1) gaženje i sabijanje šumskog tla vozilima (Pandur i dr. 2014, Poršinsky i dr. 2011), 2) oštećivanje nedoznačenih stabala i pomlatka (Danilović i dr. 2015, Petreš 2006, Pičman i dr. 2003, Poršinsky i Ožura 2006, Sabo 2003), i 3) pojavu erozionih procesa na šumskim prometnicama (Bajrić i Sokolović 2015, Efta i Chung 2014, Gumus i dr. 2008, Papa i dr. 2015, Pellegrini i dr. 2013).

\subsubsection{Prikaz postojeće geometrijske (euklidske) udaljenosti privlačenja drva - Existing geometric (euclidean) timber extraction distance}

Geometrijska (euklidska) udaljenost privlačenja drva ${ }^{* * *}$, određena metodom pravilne mreže točaka (razmaka $10 \times$ $10 \mathrm{~m}$ ) na slikovnom prikazu (zemljovidu mjerila M 1:25000 ili krupnijem) vizualizira otvorena, nedovoljno otvorena i neotvorena šumska područja. U kombinaciji s poznavanjem gustoće primarne šumske prometne infrastrukture, izračunate na temelju registra i definiranih kriterija određivanja gustoće primarne šumske prometne infrastrukture, geometrijska (euklidska) udaljenost privlačenja drva je dobar pokazatelj kvalitete prostornog rasporeda primarnih šumskih prometnica.

Posebno valja istaći, da u analizu geometrijske (euklidske) udaljenosti privlačenja drva ne ulaze oni segmenti primarne šumske prometne infrastrukture, koji iz Registara javnih i nerazvrstanih cesta te šumskih cesta gospodarskih jedinica

*** Geometrijska udaljenost privlačenja drva je najkraća udaljenost od zadane točke u prostoru do najbliže ceste (Segebaden 1964). Isti autor, pomoću metode pravilne mreže točaka definira i srednju geometrijska udaljenost privlačenja drva neke površine šuma, kao »aritmetičku sredinu geometrijskih udaljenosti privlačenja drva beskonačnoga broja točaka jednoliko raspoređenih predmetnom površinom, pri čemu svaka točka predstavlja beskonačno malu površinu«. Ovaj pokazatelj otvorenosti šuma, u sebi sadrži nepravilnosti: 1) oblika šumske površine, te 2) nepravilnost mreže šumskih cesta. Bumber (2011) i Đuka (2014) navode da je euklidska udaljenost (izračunata putem računalnog programa ArcGIS, alat Euclidean distance unutar alata Spatial Analyst) izuzetno dobar alat za određivanje prosječne geometrijske udaljenosti privlačenja drva na razini gospodarske jedinice, odnosno srednjih geometrijskih udaljenosti privlačenja drva pojedinih odjela/odsjeka. Isti autori, navode da euklidska udaljenost odgovara Segebadenovim (1964) temeljima određivanja srednje geometrijske udaljenosti privlačenja drva. Uz navedene, euklidsku udaljenost kao pokazatelj otvorenosti šuma u literaturi je koristio cijeli niz autora: Danilović i dr. 2013, Enache i dr. 2015, Laschi i dr. 2016, Lepoglavec 2014, ... ne zadovoljavaju osnovni/eliminacijski kriterij određivanja gustoće primarne šumske prometne infrastrukture, odnosno koji ne otvaraju površinu gospodarske jedinice (kolona 8 , tablice 1 i 2 ). Navedeno je vidljivo na slici 2 , gdje su iz analize postojeće geometrijske udaljenosti privlačenja drva gospodarske jedinice »Javornik - Tisov vrh« isključene ceste sa oznakama: 645A1004 i 645A3003 (potpuno), 645A1001 (gotovu u potpunosti, osim segmenta od $302 \mathrm{~m}$ uz granicu odsjeka 75b i 76b), odnosno djelomično segmenti cesta s oznakama 645A3005, 645A3006, 645B1011, 646B2001 i 646B2007. Prosječna geometrijska (euklidska) udaljenost privlačenja drva gospodarske jedinice »Javornik - Tisov vrh« iznosi $210 \pm 101 \mathrm{~m}$, a kreće se u rasponu od 0 do $1737 \mathrm{~m}$.

Tablični prikaz postojeće geometrijske (euklidske) udaljenosti privlačenja drva (prosječne vrijednosti odjela/odsjeka) u kombinaciji s drvnom zalihom i ukupnim desetogodišnjim bruto etatom na razini odjela/odsjeka, omogućava još detaljniji uvid u kvalitetu prostornog rasporeda primarne šumske prometne infrastrukture (prilog B.8 Elaborata).

\subsubsection{Prikaz raščlambe primarne relativne} otvorenosti za postojeću primarnu šumsku prometnu infrastrukturu - Existing primary forest traffic infrastructure network relative openness

Primarna relativna otvorenost ${ }^{* * * *}$, slično kao i geometrijska (euklidska) udaljenost privlačenja drva, na slikovnom prikazu (zemljovidu mjerila M 1:25000 ili krupnijem) zorno prikazuje otvorena (dostupna), nedovoljno otvorena i neotvorena (nedostupna) šumska područja za ciljanu geometrijsku udaljenost privlačenja drva pojedinog reljefnog područja (poglavlje 2.2.5). Neotvorene šumske površine su, uz uvjet ispunjavanja dodatnih kriterija, područja mogućeg budućeg zahvata primarnog otvaranja šuma s ciljem unaprjeđenja/optimizacije postojeće mreže primarne šumske prometne infrastrukture.

Dodatno, primarna relativna otvorenost se u kombinaciji s koeficijentom učinkovitosti postojeće mreže primarne šumske prometne infrastrukture koristi za detaljniju analizu

**** Relativna otvorenost, kao kvalitativan pokazatelj analize otvorenosti šuma, predstavlja omjer prometnicama otvorene i ukupne površine šuma (Backmud 1966), gdje se otvorenom smatra ona površina, koja se nalazi unutar omeđene površine (pojasa otvaranja) koja prati tijek određene prometnice. Izvorno, Backmund (1966) je predložio da širina pojasa otvaranja bude jednaka teorijskom razmaku između šumskih cesta. Kasnije u istraživanjima, širinu pojasa otvaranja šuma autori modificiraju s obzirom na namjenu, ciljeve i potrebe istraživanja (Bumber 2011, Đuka 2014, Hentschel 1996, Lünzmann 1968, Sach 1968, Pentek 2002, Pentek i dr. 2010, Pičman i Pentek 1998, Pičman i dr. 2011) 


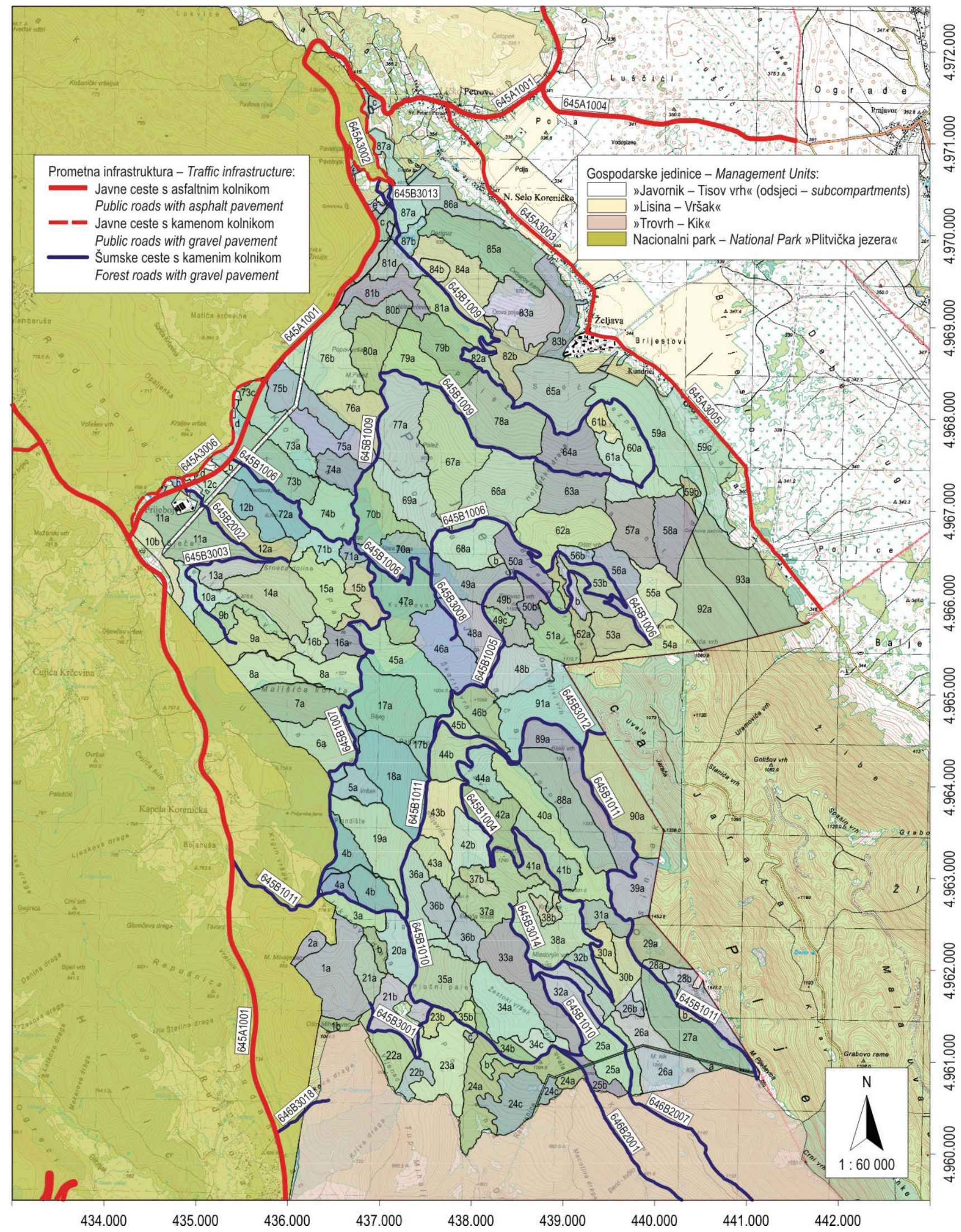

Slika 3. Karta raščlambe postojeće primarne relativne otvorenosti za postojeću primarnu šumsku infrastrukturu gospodarske jedinice "Javornik - Tisov vrh» (prilog B.9 Elaborata)

Fig. 3 Existing primary forest traffic infrastructure network relative openness in management unit »Javornik - Tisov Vrh» (Effectiveness Study Appendix B.9) 
kvalitete prostornog rasporeda/učinkovitosti postojeće mreže primarne šumske prometne infrastrukture ili njene pojedine sastavnice.

U tabličnom su prikazu raščlambe primarne relativne otvorenosti za postojeću primarnu šumsku prometnu infrastrukturu (prilog B.10. Elaborata) na jednom mjestu objedinjeni i pregledno prikazani svi parametri potrebni za donošenje kvalitetnih odluka u zahvatu primarnog otvaranja šuma.

Primarna relativna otvorenost se na temelju udjela dostupne šumske površine za definiranu ciljanu geometrijsku udaljenosti privlačenja drva pripadajuće kategorije reljefnoga područja, u Elaboratu procjenjuje kako slijedi: 1) nedovoljna (dostupno $<55 \%$ šumske površine), 2) slaba (dostupno od 55 do $65 \%$ šumske površine), 3) dobra (dostupno od 65 do $75 \%$ šumske površine), 4) jako dobra (dostupno od 75 do $85 \%$ šumske površine) te 5 ) izvrsna (dostupno $>85 \%$ šumske površine).

Pri analizi primarne relativne otvorenosti, isto kao i kod analize geometrijske udaljenosti privlačenja drva, ne ulaze oni segmenti primarne šumske prometne infrastrukture, koji ne zadovoljavaju osnovni/eliminacijski kriterij određivanja gustoće primarne šumske prometne infrastrukture, odnosno koji ne otvaraju površinu gospodarske jedinice. Rezultati analize primarne relativne otvorenosti gospodarske jedinice »Javornik - Tisov vrh « za ciljanu geometrijsku udaljenost privlačenja drva od $200 \mathrm{~m}$ (slika 3), ukazali su na slijedeću strukturu otvorenosti površina: 1741,06 ha jednostruko otvorene površine GJ, 334,26 ha višestruko otvorene površine GJ, 2001,14 ha neotvorene površine GJ, te 251,50 ha otvorene površine izvan GJ. Na osnovi polučenih rezultata raščlambe strukture (ne)otvorenih površina, primarna relativna otvorenost za postojeću primarnu šumsku prometnu infrastrukturu gospodarske jedinice »Javornik - Tisov vrh « iznosi 50,9\% (nedovoljna primarna relativna otvorenost), uz koeficijent učinkovitosti 71,8 \%.

\subsection{Planiranje/projektiranje idejne trase šumske ceste na karti i na terenu (Sastavnica C. Elaborata) - Planning of forest road concept design alingment on map and in the field (Effectiveness Study Component $\mathrm{C}$.)}

Planiranje/projektiranje idejne trase šumske ceste na karti i na terenu, odnosi se na planiranje šumskih cesta na taktičkoj, ali i na operativnoj razini. Na taktičkoj se razini otvaraju neotvorena ili nedovoljno otvorena šumska područja te unaprijeđuje mreža primarne šumske prometne infrastrukture u cjelini, dok se na operativnoj razini između više inačica nultih linija jedne idejne trase šumske ceste odabire najbolja, konačna inačica nulte linije koja se u fazi projektiranja koristi kao polazište za uklapanje osovinskog poligona šumske ceste.
Obavezni prilozi sastavnice C. Elaborata su:

1. Slojnička karta (s ucrtanom postojećom primarnom šumskom prometnom infrastrukturom, hidrografskom mrežom, granicom gospodarske jedinice i unutarnjom podjelom) s projektiranim inačicama nulte linije ( $M$ 1:5000 ili krupnije, ekvidistanta e $=1(5) \mathrm{m}$ )

2. Slojnička karta (s ucrtanom postojećom primarnom šumskom prometnom infrastrukturom, hidrografskom mrežom, granicom gospodarske jedinice i unutarnjom podjelom) s odabranom najboljom konačnom inačicom nulte linije (obilježenom nul linijskim poligonom) (M 1:5000 ili krupnije, ekvidistanta e = 1 (5) m)

3. Skraćeni tehnički opis idejne trase buduće šumske ceste predstavljene najboljom, konačnom inačicom nulte linije (tabelarni prikaz)

\subsection{Analiza unaprijeđene mreže primarne šumske prometne infrastrukture (Sastavnica D. Elaborata) - Analysis of improved primary forest traffic infrastructure network (Effectiveness Study Component D.)}

Nakon provedbe unaprjeđenja primarne šumske prometne infrastrukture planiranjem/projektiranjem idejne trase/ trasa šumskih cesta na karti, vrlo jednostavnom usporedbom slikovnih $\mathrm{i} /$ ili tabličnih prikaza odgovarajućih priloga postojećeg (B.) i unaprijeđenog (D.) stanja primarne šumske prometne infrastrukture se vide rezultati/učinci primarnog otvaranja šuma. Ukoliko su rezultati zadovoljavajući idejna trasa/trase budućih šumskih cesta se prihvaćaju kao konačna inačica, u suprotnom se ponovno pristupa prilogu C. Elaborata te se traži povoljnija inačica.

Obavezni prilozi sastavnice D. Elaborata su:

1. Slojnička karta gospodarske jedinice s ucrtanom granicom gospodarske jedinice, unutarnjom podjelom i registrom unaprijeđene primarne šumske prometne infrastrukture (M 1:25000 ili krupnije, a slojnice sa TK 25)

2. Registar unaprijeđene primarne šumske prometne infrastrukture gospodarske jedinice (tablični prikaz)

3. Karta unaprijeđene geometrijske (euklidske) srednje udaljenosti privlačenja drva gospodarske jedinice (M 1:25000 ili krupnije)

4. Prikaz unaprijeđene geometrijske udaljenosti privlačenja drva, drvne zalihe i ukupnog desetogodišnjeg brutto etata po odjelima/odsjecima gospodarske jedinice (tablični prikaz)

5. Raščlamba primarne relativne otvorenosti za unaprijeđenu primarnu šumsku prometnu infrastrukturu u gospodarskoj jedinici (M 1:25000 ili krupnije)

6. Raščlamba primarne relativne otvorenosti za unaprijeđenu primarnu šumsku prometnu infrastrukturu u gospodarskoj jedinici (tablični prikaz) 
7. Rekapitulacija parametara procjene kvantitete i kvalitete unaprijeđene mreže primarnih šumskih prometnica u gospodarskoj jedinici (tablični prikaz)

\subsection{Rekapitulacija i ocjena opravdanosti primarnog otvaranja šuma (Sastavnica E. Elaborata) - Assesment of primary forest opening suitability (Effectiveness Study Component E.)}

Rekapitulacija i ocjena opravdanosti primarnog otvaranja šuma, predstavlja vrednovanje idejne trase buduće šumske ceste, u obliku tabličnoga priloga, u kojemu su radi lakše kontrole Elaborata i ocjene opravdanosti daljnjeg primarnog otvaranja šuma, objedinjeni te pregledno i jednostavno prikazani rezultati po svim sastavnicama, odnosno prilozima Elaborata (od A. do D.). Dodatno su u tablici istaknuti najvažniji rezultati Elaborata te kriteriji odabira/rangiranja ulaganja.

\section{USPOREDBA ELABORATA UČINKOVITOSTI PRIMARNE ŠUMSKE PROMETNE INFRAS- TRUKTURE I STUDIJE PRIMARNOG OTVAR- ANJA ŠUMA COMPARATION OF THE EFFECTIVENESS STUDY OF PRIMARY FOREST ROAD TRAFFIC INFRA- STRUCTURE AND STUDY OF PRIMARY FOREST OPENING}

Elaborat je dokument osmišljen za provedbu jednokratne analize učinkovitosti postojeće i eventualno unaprijeđene mreže primarne šumske prometne infrastrukture gospodarske jedinice ili većeg šumskog kompleksa (grupa odjela/ odsjeka) koji je predmet zahvata primarnog otvaranja šuma uz planiranje/projektiranje idejne trase/trasa budućih šumskih cesta predstavljenih najboljim, konačnim inačicama nultih linija, u provedbi postupka sufinanciranja ulaganja u šumsku prometnu infrastrukturu financijskim sredstvima iz Programa.

Studija je dokument obuhvatniji od Elaborata, njegov je cilj optimizirati količinu, kvalitetu/tehničke značajke, prostorni raspored i upravljanje/gospodarenje cjelokupnom mrežom primarne šumske prometne infrastrukture pojedine gospodarske jedinice u razdoblju od najmanje 10/20 godina. Broj sastavnica Studije je veći nego li broj sastavnica Elaborata. Također je veći i broj priloga usporedivih sastavnica u Studiji nego li u Elaboratu.

Neke od sastavnica Studije ne mogu se pronaći u Elaboratu, kao npr.: 1) troškovna sastavnica (predviđena cijena koštanja) i ekonomska opravdanost izgradnje svake idejne trase planirane šumske ceste, 2) dinamika izgradnje cjelokupne (optimalne/najbolje moguće) buduće mreže primarne šumske prometne infrastrukture usklađena s propisanim radovima u šumskogospodarskim planovima, 3) dinamika odr- žavanja cjelokupne (optimalne/najbolje moguće) buduće mreže primarne šumske prometne infrastrukture i dr.), a neke se sastavnice Studije nalaze u Elaboratu, ali u reduciranom/jednostavnijem obliku.

Analiza unaprijeđene mreže primarne šumske prometne infrastrukture kod Elaborata se u pravilu i najčešće provodi za jednu idejnu trasu buduće šumske ceste. Samo u slučaju kompleksnog ulaganja, odnosno ulaganja kod kojega se gospodarska jedinica ili veći šumski kompleks otvara ne jednom već $s$ više šumskih cesta, analiza unaprijeđene mreže primarne šumske prometne infrastrukture provodi se odvojeno za svaku idejnu trasu buduće šumske ceste (sukcesivna analiza), a završni se rezultati prikazuju i u zbirnoj, konačnoj tablici za sve novoplanirane sastavnice unaprijeđene primarne šumske prometne infrastrukture (prilog E.1. Elaborata).

U Studiji se optimizira kompletna mreža primarne šumske prometne infrastrukture, nudi se cjelovito dugoročno rješenje, a rezultat je optimalna/najbolja moguća mreža primarne šumske prometne infrastrukture s obzirom na dominantne utjecajne čimbenike (i njihovu stalnost/održivost) koji su u postupku optimizacije uzeti u obzir. Studija se može, ali se u pravilu ne bavi operativnim (detaljnim) planiranjem pojedine trase buduće šumske ceste kao što to čini Elaborat (sastavnica C.). To je i razumljivo; Elaboratu, s vrlo kratkim vremenskim odmakom, slijedi izrada glavnog projekta svake šumske ceste, a operativno planiranje rezultira nultom linijom koja je polazište za uklapanje osovinskog poligona (kojim započinje podfaza Trasiranja faze Projektiranja).

Ukratko, Studija je provedbeni dokument čija se »težina« i značaj, sa stajališta uspostavljanja optimalne/najbolje moguće mreže primarne šumske prometne infrastrukture te njezinim upravljanjem, može usporediti s šumskogospodarskim planom (Gospodarskom osnovom/Programom gospodarenja) kada govorimo o gospodarenju šumama na razini gospodarske jedinice.

U Programu i u Pravilniku, kao temeljnim dokumentima na koje se Elaborat veže, su kao prihvatljive gornje granice gustoće primarne šumske prometne infrastrukture po reljefnim područjima od EU navedene vrijednosti koje su manje od vrijednosti definiranih tijekom strategijskog planiranja mreže primarne šumske prometne infrastrukture $u$ Republici Hrvatskoj (Pentek i dr. 2014) i koje bi trebale biti polazište pri taktičkom planiranju mreže primarne šumske prometne infrastrukture i izradi Studije.

Te se vrijednosti po reljefnim područjima razlikuju od 3,00 $\mathrm{km} / 1000$ ha (nizinsko i krško reljefno područje) do 7,50 $\mathrm{km} / 1000$ ha (planinsko (gorsko) reljefno područje), a iznose kako slijedi: 1) nizinsko reljefno područje - 12,50/15,00 $\mathrm{km} / 1000$ ha, 2) brdsko (prigorsko) reljefno područje $18,00 / 25,00 \mathrm{~km} / 1000 \mathrm{ha}, 3$ ) planinsko (gorsko) reljefno po- 
dručje 22,50/30,00 km/1000 ha i 4) krško reljefno područje $12,00 / 15,00 \mathrm{~km} / 1000$ ha.

Kod Elaborata se, za razliku od Studije, gotovo nikada, osim u rijetkim i izdvojenim slučajevima, i to samo kada bi prihvatljive (definirane od strane EU) i strategijskim planiranjem definirane (Pentek i dr. 2012) vrijednosti gustoće primarne šumske prometne infrastrukture bile istovjetne, na razini gospodarske jedinice ne dostižu parametri koji su pokazatelj optimalne mreže primarne šumske prometne infrastrukture.

\section{ZAKLJUČNA RAZMATRANJA FINAL CONCLUDIONS}

Studija kao dokument u kojemu su objedinjeni svi rezultati taktičkog planiranja mreže primarne šumske prometne infrastrukture na razini gospodarske jedinice i za razdoblje od 10/20 godina nema alternativu.

Studiju treba, putem zakonskih i podzakonskih akata, čim prije, s ciljem kvalitetnijeg svekolikog gospodarenja šumom i šumskim zemljištem, a poglavito primarnom šumskom prometnom infrastrukturom, implementirati u operativno šumarstvo.

Iako se i Elaborat i Studija prevladavajuće bave taktičkim planiranjem, Elaborat nije i ne može biti zamjena za Studiju.

Elaborat je kreiran na izričiti zahtjev EU kao dokument kojim će se analizirati i ocijeniti kvantiteta i kvaliteta prostornog rasporeda primarne šumske prometne infrastrukture određene gospodarske jedinice, utvrditi potreba njezina daljnjeg primarnog otvaranja te definirati položaj idejnih trasa planiranih primarnih šumskih prometnica.

Elaborat je dobro prijelazno rješenje iz situacije koju smo u svezi s planiranjem primarne šumske prometne infrastrukture na taktičkoj razini u Republici Hrvatskoj imali/imamo, kao situaciji kakvu bi u što kraćem razdoblju u našoj državi željeli imati. Potrebno je provesti određene "kozmetičke» zahvate, kako bi Elaborat u budućnosti bio jednostavniji, pregledniji, provjerljiviji i usporedljiviji.

I u slučaju Elaborata pokazalo se slijedeće: 1) iako smo i sami svjesni određenih nedostataka koji su u složenom postupku gospodarenja šumom i šumskim zemljištem prisutni, u ovom slučaju povezanih s šumskom prometnom infrastrukturom, ništa ne činimo kako bi uočene nedostatke uklonili/umanjili, već ih jednostavno ignoriramo i 2) potrebna je inicijativa/pritisak »sa strane « kako bi angažirali svoje nesumnjive znanstvene i stručne potencijale te prije spomenute nedostatke vrlo kvalitetno uklonili/umanjili.

Treba vjerovati (ali i djelovati) kako će do uvođenja Studije kao zakonske obaveze Elaborat, koji je sada obveza samo u slučaju financiranja ulaganja (izgradnje/rekonstrukcije šumske ceste) sredstvima EU, postati standard pri izgrad- nji/rekonstrukciji šumskih cesta u Republici Hrvatskoj neovisno o izvoru financiranja ulaganja. Jednom dosegnuti standardi se ne bi smjeli umanjivati.

\section{ZAHVALA ACKNOWLEDGEMENTS}

Istraživanje je provedeno u sklopu znanstvenoistraživačkoga projekta »Razredba terena za šumarstvo i razvoj tehnologija pridobivanja drva« koji financira trgovačko društvo »Hrvatske šume« d.o.o Zagreb.

\section{LITERATURA REFERENCES}

- Backmund, F., 1966: Kennzahlen für den Grad der Erschließung von Forstbetrieben durch autofahrbare Wege. Forstwissenschaftliches Centralblatt 85(11-12): 342-354.

- Bajrić, M., Sokolović, Dž., 2015: Rehabilitation of a Secondary Network of Forest Traffic Infrastructure (Skid roads - Skid Trails). Bulletin of The Faculty of Forestry Beograd, Special Issue, 5-13.

- Beuk, D., Tomašić, Ž., Horvat, D., 2007: Status and Development of Forest Harvesting Mechanization in Croatian State Forestry. Croat. j. for. eng. 28(1): 63-82.

- Brajković, S., 1997: Sadašnja i optimalna otvorenost G.J. Topolovac-model za nizinske šume Spačvanskog bazena. Magistarski rad, Šumarski fakultet Sveučilišta u Zagrebu, 1-167.

- Bumber, Z., 2011: Primjena GIS-a pri analizi otvorenosti GJ Šiljakovačka dubrava II kroz strukturu prihoda drva u prostoru i vremenu. Magistarski rad, Šumarski fakultet Sveučilišta u Zagrebu, 1-139.

- Cavalli, R., Grigolato, S., 2009: Influence of characteristics and extension of a forest road network on the supply cost of forest woodchips. Journal of Forest Research 15(3): 202-209.

- Chung, W., Stückelberger, J., Aruga, K., Cundy, T.W., 2008: Forest road network design using a trade-off analysis between skidding and road construction costs. Can. J. For. Res. 38(3): 439448.

- Contreras, M., Chung, W., 2007: Computer approach to finding an optimal log landing location and analyzing influencing factors for ground-based timber harvesting. Can. J. For. Res. 37(2): 276-292.

- Contreras, M., Chung, W., 2011: A modeling approach to estimating skidding costs of individual trees for thinning operations. Western Journal of Applied Forestry 26(3): 133-146.

- Çalişkan, E., 2013: Planning of forest road network and analysis in mountainous area. Life Science Journal 10(2): 2456-2465.

- Danilović, M., Stojnić, D., Novković, N., Gačić, D., 2013: The state of forest roads and determining an optimum density of a forest road network using GIS. Forest review 44: 6-10.

- Danilović M., Stojnić D., 2014: Assessment of the State of a Forest Road Network as a Basis for Making a Program of Forest Management Unit Opening. Bulletin of The Faculty of Forestry Beograd 110: 59-72.

- Danilović, M., Grujović, D., Milovanović, B., Karić, S., 2014: Ocjena modificirane poludeblovne metode listača s dijelovima krošnje. Nova meh. šumar. 35: 35-50. 
- Danilović, M., Kosovski, M., Gačić, D., Stojnić, D., Antonić, S., 2015: Damage to Residual Trees and Regeneration During Felling and Timber Extraction in Mixed and Pure Beech Stands. Šum. list 139(5-6): 253-262.

- Demir, M., 2007: Impacts, management and functional planning criterion of forest road network system in Turkey. Transportation Research Part A: Policy and Practice 41(1): 56-68.

- Dundović, J., 1996: Gospodarski i ekološki kriteriji za planiranje, projektiranje i građenje šumskih prometnica. Magistarski rad, Šumarski fakultet Sveučilišta u Zagrebu, 1-231.

- Đuka, A., 2014: Razvoj modela prometnosti terena za planiranje privlačenja drva skiderom. Disertacija, Šumarski fakultet Sveučilišta u Zagrebu, 1-303.

- Đuka, A., Poršinsky, T., Vusić, D., 2015: DTM Models to Enhance Planning of Timber Harvesting. Bulletin of The Faculty of Forestry Beograd, Special Issue, 35-44.

- Đuka, A., Poršinsky, T., 2015: Analiza kamenitosti i stjenovitosti terena za potrebe privlačenja drva. Nova meh. šumar. 36: 43-52.

- Đuka, A., Pentek, T., Horvat, D., Poršinsky, T., 2016: Modelling of Downhill Timber Skidding: Bigger Load - Bigger Slope. Croat. j. for. eng. 37(1): 139-150.

- Efta, J.A., Chung, W., 2014: Planning Best Management Practices to Reduce Sediment Delivery from Forest Roads Using WEPP: Road Erosion Modeling and Simulated Annealing Optimization. Croat. j. for. eng. 35(2): 167-178.

- Enache, A., Kühmaier, M., Stampfer, K., Ciobanu, V. D., 2013: An integrative decision support tool for assessing forest road options in a mountainous region in Romania. Croat. j. for. eng. 34 (1): 43-60.

- Enache, A., Pentek, T., Ciobanu, V.D., Stampfer, K., 2015: Gis Based Methods for Computing the Mean Extraction Distance and its Correction Factors in Romanian Mountain Forests. Šum. list 139(1-2): 35-46.

- Gumus, S., Acar, H.H., Toksoy, D., 2008: Functional forest road network planning by consideration of environmental impact assessment for wood harvesting. Environmental Monitoring and Assessment 142(1-3): 109-116.

- Hayati, E., Majnounian, B., Abdi, E., 2012: Qualitative evaluation and optimization of forest road network to minimize total costs and environmental impacts. iForest - Biogeosciences and Forestry 5(3): 121-125.

- Hentschel, S., 1996: GIS-gestütze Herleitung der flächenhaften Erschliessungswirkung von Wegenetzen am Beispiel von ARC/ INFO. Forsttechnische informationen, 1-2: 8-13.

- Hodić, I., Jurušić, Z., 2011: Analiza primarne otvorenosti šuma kojima gospodare HŠ d.o.o. Zagreb kao podloga za kreiranje buduće politike izgradnje šumskih cesta. Šum. list 135(9-10): 487-499.

- Hribernik, B., Potočnik, I., 2013: Forest Opening in Multipurpose Private Forest - Case Study. Nova meh. šumar. 34: 29-37.

- Huber, C., Stampfer, K., 2015: Efficiency of Topping Trees in Cable Yarding Operations. Croat. j. for. eng. 36 (1): 185-194.

- Kiss, K., Malinen, J., Tokola, T., 2015: Forest road quality control using ALS data. Can. J. For. Res. 45(11): 1636-1642.

- Krč, J., Beguš, J., 2013: Planning Forest Opening with Forest Roads. Croat. j. for. eng. 34(2): 217-228.

- Krč, J., Košir, B., 2008: Predicting Wood Skidding Direction on Steep Terrain by DEM and Forest Road Network Extension. Croat. j. for. eng. 29(2): 177-188.
- Kühmaier, M., Stampfer, K., 2010: Development of a Multi-Attribute Spatial Decision Support System in Selecting Timber Harvesting Systems. Croat. j. for. eng. 31(2): 75-88.

- Laschi, A., Neri, F., Brachetti Montorselli, N., Marchi, E., 2016: A Methodological Approach Exploiting Modern Techniques for Forest Road Network Planning. Croat. j. for. eng. 37(2): 319-331.

- Lepoglavec, K., 2014: Optimizacija primarne i sekundarne šumske prometne infrastrukture nagnutih terena. Doktorska disertacija, Šumarski fakultet Sveučilišta u Zagrebu, 1-341.

- Lugo, A.E., Gucinski, H., 2000: Function, effects, and management of forest roads. Forest Ecology and Management 133(3): 249-262

- Lünzmann, K., 1968: Der erschliessungs koefizient, eine Kennzahl zur Beurteilung von Waldwegenetzen und seine Anwendungbei Neuplanungen. Forstwissenschaftliches Centralblatt 87(1): 237-248.

- Marčeta, D., Petković, V., Košir, B., 2014: Comparison of Two Skidding Methods in Beech Forests in Mountainous Conditions. Nova meh. šumar. 35: 51-62.

- Mihelič, M., Krč, J., 2009: Analysis of Inclusion of Wood Forwarding into a Skidding Model. Croat. j. for. eng. 30(2): 113-125.

- Pandur, Z., Poršinsky, T., Šušnjar, M., Zorić, M., Vusić, D., 2014: Gaženje tla pri izvoženju drva forvarderom u sječinama hrasta lužnjaka. Nova meh. šumar. 35: 23-34.

- Papa, I., Pentek, T., Lepoglavec, K., Nevečerel, H., Poršinsky, T., Tomašić, Ž., 2015: Metodologija izradbe detaljnog registra primarne šumske prometne infrastrukture kao podloge za planiranje i optimizaciju radova održavanja šumskih cesta. Šum. list 139(7-8): 311-328.

- Papa, I., Pentek, T., Nevečerel, H., Lepoglavec, K., Đuka, A., Šafran, B., Risović, S., 2015: Raščlamba tehničkih značajki i sustava odvodnje postojećih šumskih cesta radi utvrđivanja potrebe njihove rekonstrukcije - Studija slučaja za G.J. »Belevine« NPŠO Zalesina. Šum. list 139(11-12): 497-519.

- Pellegrini, M., Grigolato, S., Cavalli, R., 2013: Spatial MultiCriteria Decision Process to Define Maintenance Priorities of Forest Road Network: an Application in the Italian Alpine Region. Croat. j. for. eng. 34(1): 31-42.

- Pentek, T., 2002: Računalni modeli optimizacije mreže šumskih cesta s obzirom na dominatne utjecajne čimbenike. Doktorska disertacija, Šumarski fakultet Sveučilišta u Zagrebu, 1-271.

- Pentek, T., Pičman, D., Nevečerel, H., 2004: Srednja udaljenost privlačenja drva. Šum. list 128(9-10): 545-558.

- Pentek, T., Pičman, D., Nevečerel, H., 2005: Planiranje šumskih prometnica - postojeća situacija, determiniranje problema i smjernice budućeg djelovanja. Nova meh. šumar. 26: 55-63.

- Pentek, T., Pičman, D., Potočnik, I., Dvorščak, P., Nevečerel, H., 2005: Analysis of an Existing Forest Road Network. Croat. j. for. eng. 26(1): 39-50.

- Pentek, T., Nevečerel, H., Pičman, D., Poršinsky, T., 2007: Forest Road Network in the Republic of Croatia - Status and Perspectives. Croat. j. for. eng. 28(1): 93-106.

- Pentek, T., H. Nevečerel, T. Poršinsky, D. Pičman, K. Lepoglavec, I. Potočnik, 2008: Methodology for Development of Secondary Forest Traffic Infrastructure Cadastre. Croat. j. for. eng. 29(1): 75-83.

- Pentek, T., Poršinsky, T., Šušnjar, M., Stankić, I., Nevečerel, H., Šporčić, M., 2008: Environmentally Sound Harvesting Technologies in Commercial Forests in the Area of Northern Velebit - Functional Terrain Classification. Periodicum Biologorum 110(2): 127-135. 
- Pentek, T., Nevečerel, H., Dasović, K., Poršinsky, T., Šušnjar, M., Potočnik, I., 2010: Analiza sekundarne otvorenosti šuma gorskog područja kao podloga za odabir duljine uža vitla. Šum. list 134(5-6): 241-248.

- Pentek, T., Pičman, D., Nevečerel, H., Lepoglavec, K., Papa, I., Potočnik, I., 2011: Primary forest opening of different relief areas in the Republic of Croatia. Nova meh. šumar., 32(1): 401416.

- Pentek, T., Poršinsky, T., 2012: Forest Transportation Systems as a Key Factor in Quality Management of Forest Ecosystems. In: Forest Ecosystems - More than Just Trees (ed: J. A. Blanco, Y. H. Lo), In Tech, 433-464.

- Pentek, T., Nevečerel, H., Ecimović, T., Lepoglavec, K., Papa, I., Tomašić, Ž., 2014: Strategijsko planiranje šumskih prometnica u Republici Hrvatskoj - raščlamba postojećega stanja kao podloga za buduće aktivnosti. Nova meh. šumar. 35(1): 63-78.

- Petreš, S., 2006: Oštećivanje ponika i pomlatka pri privitlavanju i privlačenju oblovine traktorom LKT $81 \mathrm{~T}$ iz dovršne sječine hrasta lužnjaka. Šum. list 130(3-4): 87-100.

- Pičman, D., Pentek, T., Družić, M., 1997: Utjecaj troškova izgradnje i održavanja šumskih cesta na njihovu optimalnu gustoću u nizinskim šumama Hrvatske. Meh. šumar. 22(2): 95-101.

- Pičman, D., Pentek, T., 1998: Relativna otvorenost šumskog područja i njena primjena pri izgradnji šumskih protupožarnih prometnica. Šum. list 121(11-12): 423-435.

- Pičman, D., Pentek, T., Poršinsky, T., 2003: Prilog istraživanju oštećivanja stabala mehanizacijom za gradnju šumskih putova. Strojarstvo 45(4-6): 149-157.

- Pičman, D., Pentek, T., Nevečerel, H., Papa, I., Lepoglavec, K., 2011: Mogućnosti primjene relativne otvorenosti pri sekundarnom otvaranju šuma nagnutih terena Republike Hrvatske. Croat. j. for. eng. 32(1): 417-430.

- Poršinsky, T., M. Ožura, 2006: Oštećivanje dubećih stabala pri izvoženju drva forvarderom. Nova meh. šumar. 27: 41-49.

- Poršinsky, T., Stankić, I., Bosner, A., 2011: Ecoefficient Timber Forwarding Based on Nominal Ground Pressure Analysis. Croat. j. for. eng. 31(1): 345-356.

- Poršinsky, T., Moro, M., Đuka, A., 2016: Kutovi i polumjeri prohodnosti skidera s vitlom. Šum. list 140(5-6): 259-272.

- Potočnik I., T. Pentek, D. Pičman, 2005: Impact of traffic characteristics on forest roads due to forest management. Croat. j. for. eng. 26(1): 51-57.
- Sabo, A., 2003: Oštećivanje stabala pri privlačenju drva zglobnim traktorom Timberjack $240 \mathrm{C}$ u prebornim sastojinama. Šum. list 127(7-8): 335-346.

- Sachs, W., 1968: Wegedichte und Erschließung und Erlischließungsprozent. Forst- und Holz, 23(1963): 6-7.

- Segebaden, G., 1964: Studies of Cross-Country Transport Distances and Road Net Extension. Studia Forestalia Suecica 18: $1-70$.

- Šikić, D., Babić, B., Topolnik, D., Knežević, I., Božičević, D., Švabe, Ž., Piria, I., Sever, S., 1989: Tehnički uvjeti za gospodarske ceste. Znanstveni savjet za promet Jugoslavenske akademije znanosti i umjetnosti, Zagreb, 1-78.

- Trajanov, Z., Nestorovski, Lj., Trajkov, P., 2013A: Optimization of Skidding Distances in Mountain Conditions with Different Skidding Devices. Nova meh. šumar. 34: 21-27.

- Trajanov, Z., Nestorovski, Lj., Trajkov, P., 2013B: Transportation Costs as an Indicator for Determination of the Optimal Road Density. Forest review 44: 20-22.

- Tomašić, Ž., 2012: Razvoj tehnologije i tehničkih sredstava u pridobivanju drva s obzirom na posebnosti šuma i šumarstva u Republici Hrvatskoj. Nova meh. šumar. 33: 53-67.

- Visser, R., Stampfer, K, 2015: Expanding Ground-based Harvesting onto Steep Terrain: A Review. Croat. j. for. eng. 36(2): 321-331.

- Visser, R., Berkett, H., 2015: Effect of terrain steepness on machine slope when harvesting. International Journal of Forest Engineering 26(1): 1-9.

- * Odluka o razvrstavanju javnih cesta (NN 66/15)

- * Osnova gospodarenja za gospodarsku jedinicu Javornik - Tisov vrh (2015. - 2024.)

- * Pravilnik o uređivanju šuma (NN 111/06, NN 141/08) i (NN $79 / 15)$

- * Pravilnik o provedbi mjere M04»Ulaganja u fizičku imovinu«, podmjere 4.3. »Potpora za ulaganja u infrastrukturu vezano uz razvoj, modernizaciju i prilagodbu poljoprivrede i šumarstva«, tipa operacije 4.3.3. »Ulaganje u šumsku infrastrukturu«iz Programa ruralnog razvoja Republike Hrvatske za razdoblje 2014. - 2020. (NN 106/15)

- * Pravilnik o sadržaju, namjeni i razini razrade prometnoga elaborata za ceste (NN 140/13)

\section{Summary}

The Effectiveness Study of Primary Forest Road Traffic Infrastructure - an alternative to Study of Primary Forest Opening or just a short-term solution?

Planning forest roads, as the first, inevitable and very important stage in establishing optimal i.e. best possible primary forest traffic infrastructure network, can be on: 1. strategic, 2. tactical and 3. operational level. Strategic and tactical planning level relate to planning of the entire primary forest road network, while operational planning refers to the planning of an individual forest road. The result of the tactical planning of primary forest roads is, or at least should be, the Study of Primary Forest Opening of an individual management units (hereinafter: The Study).

The absence of legal obligation in producing the Study, the document in which all work results of tactical planning primary forest traffic infrastructure, at the management unit level, would be consolidated, is a major problem in the optimization of primary forest traffic infrastructure, particularly in unopened or insuffi- 
ciently opened forest areas. Despite frequent emphasizing to this problem and the possibilities of its solving/ reduction, a significant number of papers by various authors who have in their scientific work dealt with the issue of forest opening, research results and applicable recommendations are still not used broadly in practical forestry.

While establishing Program of Rural Development in Republic of Croatia in period from 2014 to 2020, EU authorities have requested from Croatian authorities a document which includes analysis and evaluation data, regarding the quantity and quality of the primary forest traffic infrastructure network spatial distribution of a specific management unit, which will determine the need of further primary forest opening, which will also define concept design alignment of planned forest roads and will accord primary forest road density at the tactical level with the recommended values of individual relief area categories on the strategic level of primary forest traffic infrastructure planning.

In the Bylaw on measure implementation M04 »Investments in physical assets«, by-measure 4.3 »Grant for investments in development, modernization and customization of agriculture and forestry«, operation type 4.3.3 »Investments in forest infrastructure« from the Program of Rural Development in Republic of Croatia in period from 2014 to 2020 (NN 106/15) (hereinafter: The Bylaw) holds an appendix No. 1 - Form for the Effectiveness Study of Primary Forest Road Traffic Infrastructure (hereinafter: The Effectiveness Study), which was completely satisfactory to EU authorities' requests.

This paper will: 1) critically analyze the basic components of the Effectiveness Study with special emphasis on the component B - Analysis of the existing primary forest traffic infrastructure network, 2) explain in details the methodology of primary forest traffic infrastructure registry production, 3) describe the newly defined criteria for determining density of primary forest road infrastructure, 4) define the relationship and differences of the Effectiveness Study and the Study of Primary Forest Opening, and 5) give recommendations on future activities aimed at improving tactical planning of primary forest traffic infrastructure.

KEY WORDS: tactical planning of primary forest roads, Effectiveness Study of Primary Forest Road Traffic Infrastructure, Primary Forest Traffic Infrastructure Registry, criteria for determining density of primary forest road infrastructure, Study of Primary Forest Opening 